University of Nebraska - Lincoln

DigitalCommons@University of Nebraska - Lincoln

Faculty Publications, College of Journalism \& Journalism and Mass Communications, College Mass Communications

Fall 2013

\title{
Embracing Change: Exploring How Creative Professionals use Interactive Media in Advertising Campaigns
}

\author{
Adam Wagler \\ University of Nebraska-Lincoln, adamwagler@unl.edu
}

Follow this and additional works at: https://digitalcommons.unl.edu/journalismfacpub

Part of the Advertising and Promotion Management Commons, Communication Technology and New Media Commons, Graphic Communications Commons, Interactive Arts Commons, Marketing Commons, Mass Communication Commons, Public Relations and Advertising Commons, Social Media Commons, and the Technology and Innovation Commons

Wagler, Adam, "Embracing Change: Exploring How Creative Professionals use Interactive Media in Advertising Campaigns" (2013). Faculty Publications, College of Journalism \& Mass Communications. 73. https://digitalcommons.unl.edu/journalismfacpub/73

This Article is brought to you for free and open access by the Journalism and Mass Communications, College of at DigitalCommons@University of Nebraska - Lincoln. It has been accepted for inclusion in Faculty Publications, College of Journalism \& Mass Communications by an authorized administrator of DigitalCommons@University of Nebraska Lincoln. 


\title{
Embracing Change: Exploring How Creative Professionals Use Interactive Media in Advertising Campaigns
}

\author{
Adam Wagler \\ Assistant Professor of Advertising and Public Relations, College of Journalism and Mass Communications, \\ 331 Andersen Hall, University of Nebraska-Lincoln, Lincoln, NE 68588; email adamwagler@unl.edu
}

\begin{abstract}
Advertising agencies are incorporating new forms of interactive media into campaigns as media continues to rapidly change. The purpose of this phenomenological qualitative study is to explore how five creative professionals at leading advertising agencies in the Midwest are integrating interactive media into campaigns. Through a series of interviews this project helps solidify what it means to integrate interactive media. The findings illustrate a fundamental shift in an industry that is moving away from "advertising." An industry built around traditional media now requires creatives to incorporate dynamic, mobile, and social media into the marketing mix. Advertising agencies must engage audiences while embracing change by building interactivity into their "DNA." Professionals and educators will benefit from these findings that identify traits, skills, and strategies to stay current with a media environment that changes daily.
\end{abstract}

Keywords: interactive media, technology, creative process, digital, future directions

I n 2010, more than \$US 119 billion was spent on digital advertising (Smillie 2010). It is projected that by 2016 interactive advertising spending will near $\$ 77$ billion and represent $35 \%$ of all advertising in the United States (VanBoskirk 2011). Interactive media is rapidly changing the media landscape, challenging the advertising industry to develop effective means of communication in a fragmented media environment. Advertising has a long history of working with traditional print, radio, and television. Agencies must continually define and explore approaches for creative applications with the endless number of interactive media channels now available.

Previous research on interactive media in advertising has focused on three primary topics. First is the industry as a whole. Several studies and trade publications focus on new forms of measurement, new revenues streams, and the changing structures of the entire media industry. As Mallia and Windels (2011) note, "Most agencies are not set up to build digital experiences. Traditional agencies appear to be losing ground to upstarts. Perhaps because of their size and culture, they cannot remain creative and respond as quickly as modern timelines require" (p. 34). The second area centers on the rapid development of technologies that make up interactive media. Many studies cite usage statistics or list examples of applications using technology. Facebook has more than 500 million active users (Hubspot.com 2011), and as of 2007, there were more than 3 billion mobile phone consumers worldwide. This number is three times the number of personal computers in the world, which makes effective communication via mobile devices vital to communicators everywhere (Sharma, Herzog, and Melfi 2008). Third is the discussion about audience engagement strategies using interactive media. Interactive advertising is not simply the use of the latest technology, nor a display advertisement; rather it is "built around engagement, and it recognizes that people are inherently social and look to create and maintain relations not only with other people, but also with brands" (Sheehan and Morrison 2009, p. 2).

These statements leave little room for debate of the importance of interactive media in the advertising industry and continued research on the topic. Minimal research is directed at a collective understanding of how agencies strategically approach interactive media. Industry trade publications only scratch the surface through interviews with professionals. Traditional media and creative processes with mass media have been well established for decades. The ultimate outcome of this study is to develop a better understanding of how creative professionals are integrating interactive media into campaigns. This project provides insight into how future creative professionals of all ages prepare for a career in advertising. It also benefits academic and professional communities by providing insight into strategies, approaches, and future disciplines that do not yet exist as interactive media evolves. Exploring the lived experiences of a variety of creative professionals will help generate a common language and understanding of interactive media in advertising that now uses digital, mobile, and social means to engage audiences. 
An examination of multiple agency contexts, using a phenomenological qualitative approach, provides an indepth understanding of the strategies used to tackle interactive media challenges through the lived experiences of creative professionals. This discussion looks at the current understanding of interactive media in advertising campaigns, its integration into the creative process, and the changes happening in the advertising industry. For this project, interactive media is generally defined as online tools used to communicate with audiences. The purpose of this phenomenological qualitative study is to explore how five creative professionals at leading advertising agencies in the Midwest are integrating interactive media into advertising campaigns.

This project asks creative professionals how interactive media is currently being used in advertising. What approaches are used to address day-to-day changes in media? How do they engage audiences on an individual basis using interactive media? What are examples of creative uses with interactive media? How are these interactive ideas developed and designed to integrate with advertising campaigns?

\section{LITERATURE REVIEW}

The literature on interactive media in advertising frames the challenges facing the industry during a time of constant development of new technology. An analysis of previous research must begin with a definition of interactive media. This is followed by a review of the research exploring audience engagement and the social aspects created by these new interactive channels. Last is a look at the challenges facing advertising agency cultures: how they address issues, develop ideas, and attempt to keep up with the rapid changes occurring with interactive media.

Interactive media from an advertising perspective can be defined as "the degree to which a person actively engages in advertising processing by interacting with advertising messages and advertisers" (Roberts and Ko 2001, p. 21). This type of media usually refers to digital or online forms of communication where the audience members are in control of the messages they receive. Interactive advertising assumes that communication is no longer a topdown mass medium like traditional media (Griffin, Morrison, and Sheehan 2009). Advertisers are adopting less disruptive forms of communication by providing a utility based on a perceived need. A combination of technology and new strategies provides connection points for brands to continually tell their story (Martin and Todorov 2010). In addition, advertising agencies must use technology creatively across platforms in an effort to create a rich experience that engages audiences (Mallia and Windels 2011). Creativity is not using the latest and greatest new technology; rather, it is about engagement, and people's need to be social. Ad agencies want to create and build relationships with not only people but also organizations and brands (Sheehan and Morrison 2009).

Audience engagement is a complex issue involving the best ways to communicate with audiences while address- ing privacy issues. Marketers must be sensitive to the privacy of the audience and provide relevant messages to build and maintain trust (Taylor 2009). If done well, these brand utilities have the opportunity to connect with audiences much better than any 30-second commercial (Bernardin et al. 2008). Many studies have found interactive media provides a platform for online and offline brand advocacy through word of mouth (Li 2011). Conversely, if misused, a by-product of word of mouth is negative views, which are detrimental to campaign strategies (Robinson and Halle 2002).

Interactive media is inherently a social medium. A webinar by eMarketer.com states, "Any mobile marketing strategy must be social and any social marketing strategy must have a mobile component in order to effectively reach consumers" (Elkin 2010). Mobile, blogs, forums, and social networks all create space for audience members to share views, opinions, and experiences at any time and from any location. This fundamentally makes interactive media a space for building relationships through community (Mallia and Windels 2011). Push-based advertising is dying, the core model of paid advertising may also be disappearing, and in five or so years there may not be any one dominant model (Mallia and Windels 2011). Pull strategies are seen as less intrusive and allow for consumers to control the messages they would like to receive (Sheehan and Morrison 2009; Xue and Li 2008). It may even provide tools for consumers to create messages themselves, where audiences are actively involved in campaigns (Sheehan and Morrison 2009; Sasser, Koslow, and Riordan 2007). Integrated media approaches can build brands through online connections and strengthen relationships between consumers and a brand (Taylor 2009; Martin and Todorov 2010). Taken further, the consumers even become the brand and advocate for its existence through what Muniz and Schau (2007) call "vigilante marketing."

All of these issues have created rapid change in the advertising industry, because many agencies are not set up to build digital experiences for consumers who are spending increased time online (Mallia and Windels 2011). New skills and strategies are required to address these issues (Vega 2011; Bernardin et al. 2008). Large, traditional agencies are either competing with smaller boutique shops or acquiring them to address these new challenges (Sheehan and Morrison 2009). These agencies have generations of established cultures and routines, and they are slow to react to the rapidly changing media environment (Mallia and Windels 2011). Stuhlfaut (2011) describes the entrenched agency traditions and cultures as the "creative code." The creative code is a combination of a variety of internal and external variables that influences the creative work produced by advertising agencies. Furthermore, confluence theory discusses the requirement for new creative skills throughout the entire advertising agency (Sheehan and Morrison 2009). Interactive media combines multiple media, using numerous connection points to communicate with audiences. Effective advertising demands multiple disciplines beyond traditional creative departments to effectively reach consumers in a digital age. 
Griffin, Morrison, and Sheehan (2009) stress while the industry grapples with the new forms of media, the focus still must remain on the big ideas, which drive great advertising. This project extends the research by continuing to explore the process of creative and effective interactive advertising. Much of the current research looks at definitions, examples, and changes in the industry at a macro level. However, few research studies provide insights from the professionals who are addressing these issues as they happen. The rapidly changing media landscape requires continued discussions to drive the direction, philosophies, and experiences happening in the industry. This project provides a current snapshot of what is happening in the trenches with interactive media in advertising.

\section{METHODOLOGY}

A phenomenological approach to qualitative research is used in this study to develop an understanding of the challenges produced by interactive media through the lived experiences of participants. Philosophical assumptions provide a foundation for researchers when they are conceptualizing research designs, choosing qualitative methods, and selecting a specific approach (Babchuk and Badiee 2010). A constructivist world view is taken in this project to seek an understanding of the world we live in through multiple perspectives that are inductively understood by gathering and analyzing data from multiple sources to build a holistic view of the central phenomenon (Creswell 2007). These multiple realties are used to explore emerging themes to gain a better understanding of the impact interactive media is having on the creative side of the advertising industry. The application of a phenomenological approach aims to take a fresh look at individual experiences to "derive textual descriptions of the meanings and essences of the phenomenon" (Moustakas 1994, p. 34). Through the perspective of creative professionals, this study explores emerging themes to paint a picture of how interactive media is used in advertising campaigns.

A series of semistructured interviews used "the researcher as a human instrument" (Saldana 2011, p. 30) to address the complex issues that surface with interactive media in advertising. My experience as an educator and professional communicator makes it important to explore how interactive media has changed the creative profession in advertising. These experiences and connections to the industry strongly shape the interpretation of data collected for this study. During the project the researcher attempted to minimize bias using epoche by allowing the themes to emerge from the professionals. However, my close relationship to the discipline will influence the interpretation by looking for an understanding of strategies, directions, and skills now required with the addition of interactive media. It is important to understand where the profession is heading so educators can tailor curriculum to the industry and professionals can stay current with trends in media. This rapid change is a challenge to the industry but also how we educate students.
The research design was submitted and approved by the researcher's institutional review board (IRB). Five creative professionals working at advertising agencies in the Midwest were interviewed for this project. Criterion sampling was used to select creative professionals currently working at advertising agencies in the same Midwestern city. In addition, they all had to have experience working on interactive media projects. A maximum variation sampling was also used to select professionals with various backgrounds, lengths of experience, and work in different agency cultures. The participants were then approached via e-mail and asked if they would like to participate. If they agreed, a formal invitation was sent to set up a time and place that was convenient for them.

One woman and four men all under age 50 participated in the study. The job titles of the participants included creative director, art director, interactive art director, and vice president of business development. Each works at a different advertising agency. The agencies represent some of the top work produced in the region, with the majority of them located through Advertising Red Books. Each company creates unique work for a variety of industries that includes youth marketing, business to business, health care, agribusiness, and software development. The agencies the participants represent range from a large, traditional, fullservice agency to a small digital agency. Appendix 1 provides an overview comparison and further demographic information about the participants.

The semistructured interviews included open-ended questions that lasted between 20 and 30 minutes. One interview was conducted in the researcher's office, and the rest were done on-site in conference rooms at the participants' agencies. The interviews asked the participants to describe their background, the agency where they work, and their experience working on interactive media projects. The following questions were used to frame the discussion during the interview: What does the creative process look like with interactive media? Generally speaking, how do you engage with audiences using interactive media? What types of skills are involved? How do you deal with a medium that changes daily? What does "design" mean in interactive media? Appendix 2 provides the complete interview protocol.

In addition, the research analyzed recent campaigns the participants discussed during the interview to support their statements. All the work was accessed via the agencies' public websites for review. Triangulation of the work with the interviews provides tangible evidence of the perspectives and strategies used to incorporate interactive media into advertising campaigns.

Interviews were audio-recorded and transcribed by the author. Data was then imported and coded using a qualitative software data analysis program, MAXQDA. The transcripts were in vivo coded and clustered into themes that emerged from the participant responses. The themes were sorted into three categories: expected, unusual, and surprising. These findings were written into theme passages and organized to create a flowing narrative that explores the complex nature of interactive media in advertising. A 
member check was used for validation, by e-mailing participants a summary of findings. At the completion of the study, a letter thanking them for their time and a copy of the final report was sent to those who participated in the study. Appendix 3 show transcribed excerpts from two of the participants.

\section{FINDINGS}

The creative professionals who were interviewed provide expected views of interactive media that included focus on the big idea and audience engagement. The creative process is still about big ideas and reaching target audiences, but media is changing. Actively engaging audiences with interactive media creates a promise and can solidify perceptions of brands for consumers to look to for relevant information. In addition, many unique perspectives were given to frame these themes. As media evolves, the advertising industry is embracing change as it creates interactive experiences to engage audiences by developing tools, entertainment, and useful content.

New forms of interactive media are creating spaces to connect with audiences that allow brands to be part of or enhance experiences. Many participants stated they value creative, smart, and clever people who have interactive media "built into their DNA." Younger professionals, who have grown up in the digital age, have the advantage of such media seeming commonplace, thus they seem to have an innate understanding of these systems and a unique opportunity to integrate these new forms of communication into engaging experiences. In addition, agencies are attempting to make interactive media a part of their organizational culture through not labeling it as something separate. The word advertising is even up for debate in an attempt to create nonintrusive messages that are relevant to viewers. All of these findings begin with a fundamental shift in the advertising industry that is literally attempting to move away from "advertising." Appendix 4 provides a table that summarizes these findings.

\section{Interactive Advertising Does Not Like "Advertising"}

Ironically, there is discussion over the use of the term advertising. Many participants discuss this notion indirectly by using examples of less intrusive methods used to engage audiences. However, John put his finger on this idea when he mentions, "Advertising is becoming a word we don't like to use anymore and the customer doesn't like to hear anymore." This notion refers to negative reactions to traditional, interruptive forms of advertisements and the industry as a whole because of the intrusive strategies used for decades. John asks, "Why do you have to stop what they are [audiences] doing to tell your message?" Interruption is regarded as a cheap way to try to build brand loyalty and has problems.

John provides a scenario to elaborate on the annoyances caused by interruptive advertising with interactive media. Imagine you are sharing a YouTube video of a funny commercial with a friend. You send your friend the link, he or she opens it, and immediately a 15-second advertisement launches before the commercial that you wanted to share will begin to play. The 15-second commercial may or may not be relevant to the person and hinders the experience. Audiences may embrace a 4-minute advertisement if it is relevant to them or is shared with them by friends. By adding on the 15-second commercial before their content, the experience is interrupted.

Interactive media provides an opportunity to connect with audiences to tell that story in a less interruptive way. This challenges agencies to pull audiences in and provide tools or services that promote the brand. Furthermore, Bill cautioned advertisers not to jump the gun using new, interactive environments "because audiences will pass it off right away." Once a new medium is established it is required to responsibly engage audiences so brands can leverage such personal spaces as social media and mobile, which require people to opt in. All of the participants discussed how engagement with audiences using interactive media is where all brands are heading.

\section{Interactive Media Used to Engage Audiences}

Engagement is used often to describe interactive media. It is referred to as a meaningful, authentic, and interesting exchange, conversation, or transaction that creates a dynamic between the consumer and the brand. Matt discusses the value of engagement with audiences: "Brands have different goals, but ultimately the more consumers work with, believe, trust, and look to that brand, then later down the road, all this leads to sales and all things advertisers hope to accomplish." Relationships take time to build. Dave mentions the brands that are doing it well "become a little bit more human by listening, adapting, and engaging in the conversation." These methods of engagement are made up a variety of interactive media, but all give incentive to audiences by offering something of value.

Interactive media provides many ways to offer something of value, whether it be a how-to video, a story, a game, or free samples. Sarah says, "The goal is to be seen as the go-to person." Offering valuable content that consumers can use in their everyday lives or that can help them with their careers builds trust over time with the intention to influence purchasing decisions in the future. John gives an example of a car website with videos, animations, facts, and photos. You can see the entire car without ever having to go to the dealership. The experience itself can be so valuable that consumers may spend hours on the website learning about the company's products. Furthermore, the website can offer relevant conversations through customer ratings and reviews to help inform decisions.

Relevant conversations provide a space where the brand and the audience can interact. Social networks are used to facilitate these conversations, where brands push out interesting content for consumers to react to, learn from, and converse about with others. Sarah suggests that Facebook gives the opportunity to driver traffic to websites by being able to talk with the audience and potential clients. The conversations are ongoing and require meaningful responses to maintain relationships. 
All participants discussed how meaningful responses provided by relevant content could entertain, educate, and help audiences. John elaborates further on this concept of how new technology can help solve problems by understanding needs. If you need something you can just ask for it, and a meaningful response will aid the decisionmaking process. For example, if you ask your smartphone for "Chinese restaurant phone numbers," a search is run and your phone displays results that include nearby locations fitting your query. Bill described interactive cooking videos his company produced that featured embedded content with tips and tricks for making the featured recipes. Brands providing content that is a meaningful response to the context of the audience will continue to be important as more focus is put on the semantic understanding of data and engagement. Interactive media technically makes these strategies possible, but creative professionals still emphasize the importance of developing the big idea.

\section{Interactive Media Used to Develop the Big Ideas}

The big idea is still king. Developing creative ideas has always been the main focus of any creative advertising campaign. Clients come to advertising agencies to fill a need to promote or communicate a message. The ideas are how they solve that need. Dave notes that "the fundamentals of advertising are similar, and our company looks at all the new tools then selects the best solution for a particular client." The big idea now includes the integration of interactive media. John says that creative professionals develop ideas based on two principles that make up a brand: "a promise and perception."

A brand promise is a combination of logos, colors, advertising, marketing, customer service, store environment, website, social media, and so on. Everything used together develops a unified idea presented to the customer to ensure the quality and message is delivered. The second part of a brand is the perception of the consumer. If consumers do not believe what the brand is communicating, then the promise is broken. Interactive media allows for brands to communicate one on one with consumers and presents enormous opportunities. These brands now must capture the essence of their culture in their campaigns.

Matt offers Red Bull as a product that has effectively captured the essence of its brand. Advertising does not tell audiences about a product; rather, it lets them experience it firsthand. John refers to Nike as a classic example from the 1980s when they first asked the audience to "Just Do It." They didn't show their product; they presented a lifestyle and personality behind their brand. Furthermore, Sarah notes, "It is not the product per se, but the personality behind it." Bill goes on to describe the ideas that become possible with the limitless capabilities with interactive media: "A lot of our time and discovery is coming up with the craziest ideas possible, knowing and having full faith in our developers." Capturing the essence in a campaign involves interactive media, but the creative process remains very similar to traditional advertising.
All participants describe the creative process used to develop interactive media as very similar when compared to traditional advertising. Matt says, "I realized that the creative process is really the same for both [traditional and interactive media]." The specific process varies, but John demonstrates this with an example of a wire frame for a website and sketched mock-up of a magazine advertisement. Both examples outline an idea that quickly conveys it using a rough sketch. Furthermore, participants discuss design as important to all aspects of the creative process.

When asked if design principles had changed with the addition of interactive media, the overwhelming response is no. The core design principles have not changed, just the media. John notes:

When you're designing, you have to think of not just the visual aspect of it, but how is it structured? How is it received by the audience? Is it complicated? Can it be simplified? Is it convoluted? Can the process be shortened? If you need to go five steps down, can we make it so you can go just one step? Is there a reason why it was five steps to begin with? We really look at the way it is structured, which is the backbone of everything that we're doing.

Design principles include organizing information in a way the viewer can easily access it, in addition to color, form, and typography. The focus on design throughout the entire creative process is important because all media must connect and organize content in a memorable way. Sarah mentions design for print was always based on how it looked but now, with interactive media, "the messaging and where the user goes next is the most important." Dave goes on to describe that their design focus primarily emphasizes user experience and content. Bill describes print design as "flat" compared to the layers and frameworks interactive media designers build to hold content and focus on user experience. Each medium has unique aspects that require different approaches to design to successfully convey a message. Advertising agencies are embracing change as the media landscape continues to evolve with interactive media.

\section{Using Interactive Media Requires Embracing Change}

The advertising industry is built on strategic thinking and now requires agencies to embrace change as they develop creative ideas that integrate interactive media. Matt mentions that although we know technology is rapidly changing, "you have to embrace the change and the temporary nature of where we are today." Sarah expands on this by remembering, "Years ago, over a long three-day weekend, I taught myself HTML and CSS." Bill discussed how they tackle challenges as they develop ideas for interactive media: "It's exciting because we don't feel like we have limits on anything.... There are conversations with development before we pitch the idea, but most of the time it's going to get pitched anyway, and we'll just figure it out, one way or another." As the industry changes to include interactive media, the industry's professionals are updating their skills to stay current. Not everyone needs to be a programmer, but everyone must understand the inter- 
active media currently being used to stay relevant to the audience.

As media changes, Matt states, "smart, clever, creative people" who understand interactive media are in high demand at advertising agencies. Understanding the space your audience "lives in" is a requirement to create an authentic experience that holds true to the brand promise and perception. Participants mention a variety of ways their agencies and they themselves maintain an understanding of interactive media. Internal communication is important for agencies, because coworkers can share knowledge and examples they find. Such methods of internal communication might include participating in seminars, using wikis, and regularly reading blogs to learn about new technologies. Sarah talks about "lunch and learns" held in her organization to help employees understand new trends and technologies. Sharing information and specialties helps her stay up to date with interactive media. In addition, Matt adds that he requires "ten to fifteen percent of everyone's time spent understanding trends." They spend a lot of time on technology blogs and many forms of social media to understand the latest and most relevant things happening. At Bill's agency, to stay current the positions of two people are dedicated to following trends in media, technology, and design. As interactive media evolves, the media is different, but creative thinking remains key.

Different media produces new ways of communicating with audiences, but Matt points out: "You still need to be able to think big, be brilliantly innovative, clever, and relevant to an audience." He says the challenge is, rather than getting their messages in front of audiences on the television, he wants audiences to interact with brands on their mobile phones. The interaction could also be with a quick response $(\mathrm{QR})$ code, a social network, a video, or a website. These methods all have similar goals but use different media. Interactive media is now where every brand is heading as clients continuously adopt these new technologies.

The participants from traditional agencies mentioned that some clients are slow to adopt new forms of interactive media. Sarah notes, "We are really trying to push clients to think past the desktop and start thinking about the mobile device." However, every participant mentioned that his or her own firm has developers on staff to code digital products. A decade ago, programmers were not hired by many agencies; in many cases, "building a website was an afterthought," as was noted by Sarah. Clients have adopted many forms of interactive media as part of their campaigns. Now, many big ideas are generated from and even driven by the interactive applications. Bill points out that all of his company's work is now digital. Matt says that in the past three or four years every campaign his company has done has had a digital component. He continues by stating, "Eighty percent of the stuff we do is digital, social. That's where every brand is headed." As clients continue to adopt new interactive media as part of their campaign strategies, the industry continues to figure out the best ways to deliver creative solutions to client needs.

\section{Interactive Media Must Be Part of Your Core DNA}

Many agencies have problems keeping up with new interactive media because of the history and culture developed over decades of working with what is now called "traditional media." The advertising industry was built on print, radio, and television. These channels are still the primary focus of most large advertising agencies. Matt gives the analogy: if you wanted to sell a widget and went to an advertising agency for help, the ad agency's suggestion to solve your problem would be to sell you advertising. If you went to a graphic design shop, the employees there would suggest a new look, colors, logo, signage, and space. If you went to a digital agency, there would be talk about setting up an e-commerce solution. Matt concludes, "The problem here is that everyone is selling whatever it is that they already do. And I challenge that they are actually solving the problem." Advertising agencies address this issue in many different ways, but he refers to the issue as a problem with the industry's "core DNA."

To address these problems, he hires people directly out of school and tries to keep the average age in his studio around 26 to 27 years old. When asked to elaborate more on the concept of the industry DNA, Matt said:

\footnotetext{
Younger people already have the skills we are looking for in their DNA. They understand social. I don't have to teach it to them; it is part of who they are. That is one way of staying relevant. I learn from them, watch them, and observe them. In some ways, they teach me. That is how I stay relevant and how our agency stays relevant.
}

His agency is a youth branding agency, so their clients are looking to reach a younger demographic whose media usage traditionally forecasts trends that are later adopted by wider ranges of audiences. Bill's agency produces digital work only for clients. His company's culture is very much comparable to a start-up, with this mantra: "Make the real world digital and the digital world real." He goes on to describe late nights at the office as feeling like a slumber party, only they are developing new ways of interacting with content. However, looking forward to a time where all brands are focusing the majority of efforts on interactive space is vital. Advertising agencies are tackling the challenges of interactive media in a variety of different ways.

Many of the participants specifically mentioned that their agencies are in a state of transition as the media industry evolves. The transition to include more interactive media differs depending on the agency. Many of the participants say their agency does not have digital departments or interactive specialists because all team members need to be part of everything they are creating. Instead of thinking about it as something unique, they are attempting to integrate into the whole picture of media. Conversely, other agencies have interactive media departments with positions that are labeled as such: interactive art director, interactive designer, and digital producer. Currently, there is not a solidified organizational structure that all agencies have settled on as they transition into a more interactive media landscape. However, as the industry transitions 
to include an increasing amount of interactive media into advertising campaigns, agencies will continue to address challenges as they develop.

\section{DISCUSSION}

If you have recently traveled with a person under age 25, you have experienced this firsthand. Traditionally, you go on vacation, visit interesting places, take pictures to capture the memory, and share them with family and personal friends when you return. Now the paradigm has shifted. The vacation experience can be shared online through social networks, video chats, and mobile apps, enhancing these experiences as they happen. Last summer, I led a study abroad to Russia with 17 undergraduate students. Even in a foreign country, on a different continent, their photos, videos, thoughts, memories, and experiences were all shared in real time with larger networks of people who were now part of the trip. This idea transcends travel and now includes all forms of life. It is not a strategy; it is a reaction built into how young, creative individuals experience the world.

The literature on interactive media in advertising confirms some of the basic findings of this project. The term interactive media is used to describe the new forms of media available to advertising agencies. There are many changes occurring in the industry (Mallia and Windels 2011), including the need for new media, new skills, and new organizational structures. New forms of communicating also demand new skills (Vega 2011; Bernardin et al. 2008), but the big idea is still a central focus (Griffin, Morrison, and Sheehan 2009). Cultures in agencies are strong and influence how client problems are solved (Stuhlfaut 2011). Last, engagement with audiences is required for advertising agencies to continue to be successful (Sheehan and Morrison 2009).

This study contributes new elements that include discussion about the term advertising in the industry and how younger generations contribute to the industry during this transitional period. Furthermore, it identifies ways agencies are embracing change and creatively thinking about the message and the medium. This reflects McLuhan's (1964/1995) idea that "the medium is the message," where the delivery method heavily influences how the message is perceived by the audience. Developing creative departments with people who have digital media in their DNA will further the discussion, addressing questions such as these: What is advertising? In addition, will this term be replaced by other terms such as engagement, promotion, or connection?

Advertising agencies must explore the themes that emerged from these interviews to address the current and future challenges that interactive media produces. Much of the literature confirms some of the basic understandings of interactive media in advertising, but further research must be done to better understand how agencies are tackling these challenges. One option may be to embed younger professionals into traditional teams to breathe new life into traditional forms of advertising. This type of collaboration has the opportunity to create a unique environment where everyone is learning. The challenge moving forward is not only addressing current technologies but also developing sustainable practices to anticipate new developments in communication, technology, and media.

It is exciting to see how young professionals have a chance to make an impact at the beginnings of their careers. These findings create unique opportunities for higher education classrooms to develop new strategies and ways to connect with audiences. In turn, the industry will benefit from these fresh ideas because of the time spent developing big ideas that integrate interactive media. This also highlights the necessity for closer connections between the industry and higher education to collaborate in the effort to address challenges. As an instructor and professional, I know the possibilities are endless and they open doors to create new models for organizations and communications using interactive media.

The limitations of this study include a small geographic location representing a very global shift in media. These findings cannot be generalized, but an attempt was made to capture a range of agencies to be representative of many cities in the United States. All of the participants in this study work within the same downtown area, and their agencies would be considered small to midsize, but they represent different agency cultures and clients. Another limitation was access to some of the work that was analyzed. Some of the work was still in development, and other work had been changed already due to the temporary nature of interactive media. Capturing and documenting the work prior to the interviews would have provided better insights and helped develop specific questions for the interviews.

There are many possibilities for future research on interactive media in advertising. Qualitative research cannot generalize findings, but future quantitative measurements should be conducted with creative professionals to further explore the themes developed in this study. This is both an opportunity and a necessity for the future success of the industry and higher education. An interesting perspective to add to this could be from a student perspective. The term digital native is a debatable blanket term for an entire generation, but interviews with high-functioning, young media students would help agencies gain new perspectives. This would inform them and aid in the development of young professionals. Also, further exploration of other disciplines within advertising agencies contributing to the creative process with interactive media would be beneficial. For example, John's office has creative work in progress hung up throughout the entire office for anyone to comment on during its development. Many agencies have a very collaborative working environment that includes everyone in the creative process. In addition, it would be interesting to explore how clients view interactive media. Many of the participants in this study mentioned hesitation on the client side of things when implementing new forms of interactive media. All of these directions will contribute to the academic, professional, and consumer understanding of how interactive media is incorporated into advertising campaigns. 


\section{REFERENCES}

Babchuk, W. A., and M. Badiee (2010), "Realizing the potential of qualitative methodologies: A conceptual guide for research and practice," in Proceedings of the 28th Annual Midwest Research Research-to-Practice Conference in Adult, Continuing, and Community Education, J. Dirkx, ed., 25-31. Michigan State University, East Lansing, Michigan, 26-28 September 2010.

Bernardin, T., P. Kemp-Robertson, D. W. Stewart, C. Yan, H. Wan, J. R. Rossiter, S. Erevelles, R. Roundtree, G. M. Zinkhan, and N. Fukawa (2008), "Envisioning the Future of Advertising Creativity Research," Journal of Advertising, 37 (4), 131-49.

Creswell, J. (2007), Qualitative Inquiry and Research Design: Choosing Among Five Approaches, 2nd ed., Thousand Oaks, CA: Sage.

Elkin, Noah (2010), “Mobile Marketing Trends, Insights, and Best Practices" (webinar), http://www.slideshare.net/ eMarketerInc/emarketer-webinar-mobile-marketingtrends-insights-best-practices\#text-version

Griffin, G., D. K., Morrison, and K. B. Sheehan (2009), "Perspectives of Digital Creativity," Journal of Interactive Advertising, 9 (2), 63-65.

Hubspot.com (2011), "Social Media Marketing: 27 Stats, Soundbites, and Slides," http://www.hubspot.com/ social-media-slides $/$ ?source=socialmedia-slides-ebook

Li, H. (2011), "The Interactive Web," Journal of Advertising Research, 51 (1), 13-34.

Mallia, K. L., and K. Windels (2011), "Will Changing Media Change the World? An Exploratory Investigation of the Impact of Digital Advertising on Opportunities for Creative Women," Journal of Interactive Advertising, 11 (2), 30-44.

Martin, K., and I. Todorov (2010), "How Will Digital Platforms Be Harnessed in 2010 and How Will They Change the Way People Interact with Brands?," Journal of Interactive Advertising, 10 (2), 61-66.

McLuhan, M. (1995), “The Medium Is the Message," in Essential McLuhan, Eric McLuhan and Frank Zingrone, eds., New York, NY: Basic Books, 151-61. (Reprinted from Marshall McLuhan, Understanding Media: The Extensions of Man, New York: McGraw-Hill, 1964, 7-21)

Moustakas, C. (1994), Phenomenological Research Methods, Thousand Oaks, CA: Sage.

Muniz, A., and H. Schau (2007), “Vigilante Marketing and Consumer-Created Communications," Journal of Advertising, 36 (3), 187-202.

Roberts, M., and H. Ko (2001), “Global Interactive Advertising: Defining What We Mean and Using What We Have Learned," Journal of Interactive Advertising, 1 (2), 18-27.

Robinson, L., and D. Halle (2002), "Digitization, the Internet, and the Arts: eBay, Napster, SAG, and e-Books," Qualitative Sociology, 25 (3), 359-83.

Saldana, J. (2011), Fundamentals of Qualitative Research, Oxford: Oxford University Press.

Sasser, S. L., S. Koslow, and E. A. Riordan (2007), “Creative and Interactive Media Use by Agencies: Engaging an IMC Media Palette for Implementing Advertising Campaigns," Journal of Advertising Research, 47 (3), 237-56.

Sharma, C., J. Herzog, and V. Melfi (2008), Mobile Advertising: Supercharge Your Brand in the Exploding Wireless Market, Hoboken, NJ: Wiley.

Sheehan, K. B., and D. K. Morrison (2009), "The Creativity
Challenge: Media Confluence and Its Effects on the Evolving Advertising Industry," Journal of Interactive Advertising, 9 (2), 84-88.

Smillie, Dirk (2010), "Digital Lift-Off," Forbes.com, March 8, http:/ / www.forbes.com/2010/03/07/advertising-webads-digital-business-media-outsell.html

Stuhlfaut, M. W. (2011), “The Creative Code: An Organizational Influence on the Creative Process in Advertising," International Journal of Advertising, 30 (2), 283-304.

Taylor, C.R. (2009), "The Six Principles of Digital Advertising," International Journal of Advertising, 28 (3), 411-18.

Xue, D., and H. Li (2008), Creative Use of QR Codes in Consumer Communication," International Journal of Mobile Marketing, 3 (2), 61-67.

VanBoskirk, S. (2011), US Interactive Marketing Forecast, 2011 to 2016, Cambridge, MA: Forrester Research.

Vega, T. (2011), “Advertising Companies Fret Over a Digital Talent Gap," New York Times, October 30.

\section{APPENDIX 1: PARTICIPANT OVERVIEW}

\begin{tabular}{llr}
\hline Pseudonym & Job title & $\begin{array}{r}\text { Years at } \\
\text { current agency }\end{array}$ \\
\hline Sarah & Interactive art director & 6 \\
Matt & Creative director & 11 \\
Bill & Creative director & 3 \\
Dave & Vice president of business development & 20 \\
John & Art director & 6 \\
\hline
\end{tabular}

Overview of Participant Agencies

- Years founded: 1962 to 2003

- Number of employees: 20 to 115

- Location: All in the same Midwest metro area

\section{APPENDIX 2: INTERVIEW PROTOCOL}

Interview Protocol Project: Interactive Media in Advertising

Time of interview:

Date:

Place:

Interviewer:

Interviewee:

Position of interviewee:

(Briefly describe the project.)

Ask interviewee to sign consent and image release forms.

Turn on audio and video recorders.

Questions:

1. Describe your experience developing ideas using interactive media?

2. What does the creative process look like with interactive media?

3. Generally speaking, how do you engage with audiences?

4. What types of skills are involved?

5. How do you deal with a medium that changes daily?

6. What does "design" mean in new media?

7. What is interactive media for advertising agencies?

8. Who should I talk to find out more about this?

(Thank the individual for participating in this interview. Reminder there will be follow-up to verify accuracy of final report.) 


\section{APPENDIX 3: TRANSCRIPTION SAMPLES}

\section{Sarah}

You know, about five or six years ago when I started full time in the interactive department, it was more of an afterthought, I think. They would come up with the print campaign, and someone would say, "Oh yeah, we need a website" or "Oh yeah, we need a landing page" or "Oh yeah, we need digital ads. So here is our print campaign, so make it match." Luckily, today we are in the beginnings of all the meetings, and there are many times where print will come out of an interactive idea.

I think the goal is to blur those lines and try to work more cohesively with traditional print advertising and interactive. I don't know how relevant QR codes are, but some people think that they are very relevant and will continue to live and other people don't. I don't really have an opinion, but even having the QR codes on a print ad and have them direct to a mobile site. We just did a great campaign for Use Chicago where we had all these QR codes in the subway system, the L. Out there on a 20- minute ride to work we had a mobile site that had 300 videos on it that they could pull up really easily. So working together with those types of technologies, I think, is a cool thing to think about.
Matt

Well, the problem here is that everyone is selling whatever it is that they already do. And I challenge that they are actually solving the problem. We are positioned to never be locked into one particular media. So when I go to solve the problem it might be combination of architecture and digital. It might be part print advertising and it might be partway finding signage. I don't know, and I don't care until I get into it. I approached that creative process for interactive the same way I approach it for everything. Although I think our philosophy is very different than the way the creative industry is set up.

I think that somebody that goes through a traditional process, from what I can tell in the industry, would think that there's a very different process for interactive media. That might be a mindset because they have been in the history longer than I have, and so by that circumstance they think of interactive as completely different animal. Look at any advertising agency out there. They either tried to create their own interactive department or they tried to buy an interactive agency. The problem there is - and they do that because they don't understand it. So what that says to me is that it is not part of their core DNA. When you do that, you treat it separately. The future of advertising is not separate. Interactive is the future of advertising. I'm glad it's part of our core DNA and that it is not something I have to try to figure out or add in. It's already there.

I think for most agencies that's a real struggle right now. 


\section{APPENDIX 4: SUMMARY OF FINDINGS}

\section{Emergent themes}

Interactive advertising does not like "advertising."

Interactive media used to engage audiences.

Interactive media used to develop the big ideas.

Using interactive media requires embracing change.

Interactive media must be part of your core DNA.
Participant responses

John: “Advertising is becoming a word we don't like to use anymore, and the customer doesn't like to hear anymore. Why do you have to stop what they [audiences] are doing to tell your message?"

Bill cautioned advertisers not to jump the gun using new, interactive environments "because audiences will pass it off right away."

Matt: "Brands have different goals, but ultimately the more consumers work with, believe, trust, and look to that brand, then later down the road, all this leads to sales and all things advertisers hope to accomplish."

Dave: brands that are doing it well "become a little bit more human by listening, adapting, and engaging in the conversation." These methods of engagement are made up a variety of interactive media, but all give incentive to audiences by offering something of value.

Sarah: "The goal is to be seen as the go-to person."

Dave: "The fundamentals of advertising are similar, and our company looks at all the new tools then selects the best solution for a particular client."

John: Ideas based on two principles that make up a brand: "a promise and perception."

Sarah: "It is not the product per se but the personality behind it."

Bill: "A lot of our time and discovery is coming up with the craziest ideas possible, knowing and having full faith in our developers."

Matt mentions that we know technology is rapidly changing, but "you have to embrace the change and the temporary nature of where we are today."

Bill: "It's exciting because we don't feel like we have limits on anything." He continues: "There are conversations with development before we pitch the idea, but most of the time it's going to get pitched anyway and we'll just figure it out, one way or another."

Matt: "Eighty percent of the stuff we do is digital, social. That's where every brand is headed."

Matt: "Younger people already have the skills we are looking for in their DNA. They understand social. I don't have to teach it to them; it is part of who they are. That is one way of staying relevant. I learn from them, watch them, and observe them. In some ways, they teach me. That is how I stay relevant and how our agency stays relevant."

Bill's company mantra: "Make the real world digital and the digital world real." 